\title{
Strategic Political Communication of Young Business Actor Be Succes Politician
}

\author{
Muhammad David Octavian ${ }^{1}$, \\ ${ }^{1}$ Corresponding author, Magister of Communication, \\ University of Paramadina, \\ Faculty of Political Communication, \\ Jend. Gatot Subroto Street, \\ No Kav 97 Mampang Prapatan, Jakarta Selatan
}

\begin{abstract}
The aims study were to find out the steps taken by businessmen be success a politicians and strategic political communication by entrepreneurs who have succeeded in becoming politicians. This research uses a qualitative approach. In determining the informants of the researchers used informant entrepreneur Ryan Kono who is currently the deputy mayor of Gorontalo. Data collection methods in this study are the sources of literature and documentation. Based on the description of the discussion the following conclusions are explained 1) Political process of businessmen be a succes politicians carried out with the initial process Ryan Kono advanced to represent Gorontalo City in partnership with Marten A Taha. Ryan Kono is a businessman who has political instincts, and is talented. Ryan Kono was already in politics at a very young age. Ryan Kono's political career can be supported by his experience as an entrepreneur. This supports the victory of Ryan Kono with the results of voting from the elections in Gorontalo City through quick counts through the superior Vote Counting Information System (Situng) with a result of 42.665 or 41.20 percent and 2) Political communication strategies promise change and improvement of natural policies in the fields of economy, social welfare, health, using digital media as a means to market ideas, solicit support, and raise funds from their constituents. Other strategic political communications include internal Political Communication, Formation of a Success Team, Coordination and Outreach and Political Campaign
\end{abstract}

Keyword:- Actor, Business, Communication, Politician Strategic Political.

\section{INTRODUCTION}

Political communication is an effort of an entrepreneur when he becomes a politician in creating political branding to get support from the people. Scherer (2009) study explains that the relationship between business and politics is mainly built on the assumption of a reasonable regulatory environment in which nation state institutions handle issues of public concern and regulate business behavior. Sampedro (2011) found that political communication from a person who has popularity will be easier in politics. Vreese et.al (2018) explains that political communication forms a political actor becoming more popular so that it will be easier to become a politician.

\author{
AG.Eka Wenats Wuryanta ${ }^{2}$ \\ ${ }^{2 \mathrm{M}}$ Magister Magister Sains, University of of Paramadina, \\ Faculty of Political Communication \\ Jend. Gatot Subroto Street, \\ No Kav 97 Mampang Prapatan, Jakarta Selatan
}

Gelder (2003) revealed that branding is a set of identities that represent the goals to be achieved and how it is strived for. So according to him, branding is constructed on three main variables namely positioning, personality, and brand identity. Sonies (2011) explains that political branding is a strategy to distinguish themselves from competitors in a political competition that is built on three main indicators, namely political parties, actors, and policies. Indicators of political party variables are defined as ideology, culture, political track record, and reputation of the party.

Neron (2010) explains that in the business world it provides opportunities to turn entrepreneurs into political actors. The relationship between politics and companies in which there is also a political community. The relationship between companies and politics: companies as distributive agents, companies as political communities, corporate practices and policies as a matter of citizenship, and companies as active participants in the political process. Entrepreneurs who are involved in politics must have communication strategies to win their political votes. Communication in human life is something that can not be separated, both have an important role and are related to each other. Political communication is a field or discipline that examines behavior and communication activities that are political in nature, have political consequences, or affect political behavior. The role of a communication in the political world, also can not be separated in all its activities, with the communication of the delivery of political messages and political objectives will be conveyed properly as desired. Ireland et.al (2014) explains that political communication plays an important role in the government's efforts to assess government policies or the performance of government officials. Vreese et.al (2018) explains that political communication plays an important role in delivering political messages to the public.

Political communication becomes an important element to bridge communication between the political elite and civil society. Hasfi et.al (2017) explains that political communication is an important factor in building a civilized society where elites and civil society are connected. According to Rush and Althoff (2008) political communication plays a very important role in the political system: this political communication determines a dynamic element, and becomes a decisive part of political socialization, political participation, and political recruitment. 
The importance of the strategic role of political communication can also be seen from McNair's (2003) view of political communication, but the indicators of this view differ from those proposed by Rush and Althoff (2008), where McNair (2003) mentions "political communication as pure discussion about the allocation of public resources (revenues), official authority (who is given the power to make legal, legislative, and executive decisions), and official sanctions (what the state reward or punishes). From what McNair has said, political communication talks about the allocation of public resources that have value, government authorities who are given the power to make decisions in both the legislative and executive fields, and sanctions given by the government.

In an increasingly open political climate, competition becomes an inevitable logical consequence. This forces the contestants to formulate the most effective strategy to market their personal characteristics, initiatives, ideologies, political ideas, and work program designs in an effort to build trust and a positive image in the eyes of constituents. Because in a democratic system, being the best in the eyes of constituents is an absolute requirement that must be achieved by the contestants in order to gain votes and win the existing political competition.

Trust and a positive image can actually be achieved easily if the contestant can construct his identity, offer interesting political products, and plant a strong positioning of competitors into the minds of constituents. Or on the political agenda this strategy is called political branding (Philbrick and Cleveland, 2015). Political branding itself is actually an old tactic that is commonly used by political contestants to gain popularity during the election campaign. Although not necessarily guarantee victory at the hands of contestants, but political branding can be a powerful weapon in creating a different and more efficient campaign (Milewicz and Milewicz, 2014). Because by creating strong and clear branding, the impression of a political contestant will be firmly planted in the minds of constituents. And this will later become a consideration and determinant factor for constituents when they are confronted with a series of political choices or in other words strong branding will be difficult to shake by competitors and most likely will win existing political competition.

The implementation of the Regional Head Election is actually an important part of Indonesian state life in the Reformation era where almost all actors (politicians) and political parties can carry out the functions of political communication properly. Actually the success of communication by political actors will not only realize the political goals of the actors themselves, but this success can realize greater political goals, namely public support for political parties and political actors in the election of governors, the presidential election, and so on. Iazzolino and Stremlau (2017) find that political communication has an important role in the political process. This study explains that the role of political communication in elections in Kenya, South Africa. Political strategies used include using the role of the media, forming political options and listening to direct complaints from the public. Based on Williams (2016), 44\% of US citizens rely on social media for political awareness about candidates in the 2016 presidential election. It says there are nearly 10 million Trump followers on Twitter while Hillary Clinton has nearly 7 million. Yet on Facebook, Trump has nine million about doubling the number of followers. It was discovered by the Pew study that political candidates use Facebook for five to seven posts per day and use Twitter for 11 to 12 tweets per day. Hallahan, et, al (2007) defined strategic communication as "the purpose of using communication by an organization to fulfill its mission. Likewise, Frandsen and Johansen (2017) argue," all types of organizations, including the private and public sectors, are political parties, NGOs, and social movements, using strategic communication to achieve their goals Macnamara (2012) examines the use of interested parties in strategic communication to achieve goals, achieve impacts, and to address them an agenda highlighting dynamic ethical issues but little attention is paid to the use strategic political communication by politicians. The role of political actors in increasing the importance and strategic use of political communication is explored.

One of the election cases in Gorontalo City is an interesting phenomenon to be investigated related to political communication by a businessman who is one of the candidates for deputy mayor. The entrepreneur who became a politician and is currently the mayor of Gorontalo is Ryan Kono. The first time, Ryan Kono's election as Gorontalo mayor's representative was started with Marten Taha's selection of representative figures, a number of figures who were close to him were the best figures. Young businessman Ryan Kono advanced in the mayoral election in 2018. Ryan Kono advanced to become the representative of Gorontalo City in partnership with Marten A Taha. Ryan Kono is a businessman who has political instincts, and is talented. Ryan Kono was already in politics at a very young age. Ryan Kono's political career could be supported by his experience as the chairman of Gorontalo HIPMI. It did not take long to learn, especially since his father was a reliable politician. Gorontalo Deputy Mayor Ryan Kono was elected to a 2019-2024 tenure by Gorontalo Governor Rusli Habibie at home.

Ryan Kono's personal branding belongs to Ryan Kono's advantage as a businessman opening up the opportunity for him to win the election as deputy mayor of Gorontalo. Entrepreneur Ryan Kono has a strategy to successfully get votes and be elected as people's representatives. Therefore, the existence of political communication plays an important role in the political achievement of candidates for the people's representatives. Communication itself is a process and activity of delivering an information or message from the communicator to the communicant, which later the communicant will respond to what has been conveyed by the communicator. Communication is a very fundamental need for someone in social life (Cangara, 2012). The focus of attention that actually becomes the focus of research is the winning 
political communication strategy used by Ryan Kono as an entrepreneur in the Gorontalo city elections in 2018 last. In this perspective, it is interesting to study the political communication of Ryan Kono's candidates who come from business people, especially political communications from political actors.

\section{THE PURPOSE}

The aim of this research were:

$>$ To find out the steps taken by businessmen politicians be success a politicians.

To find out strategic political communication by entrepreneurs who have succeeded in becoming politicians.

\section{LITERATURE REVIEW}

\section{$>$ Political communication}

Communication is the process of social interaction that people use to arrange meaning which is their image of the world (on which they act) and to exchange that image through symbols (Dan Nimmo, 2005). Politics are various activities in a political system (or state) that involve the process of determining these goals. Decision making (decision making) about whether the objectives of the political system involves the selection of several alternatives and the priority scale chosen goals. To implement this policy, it is necessary to have power and authority, which will be used both to foster cooperation and to resolve conflicts that may arise in this process. The method used can be persuasive (convincing) and if necessary is coercion (coercion). Without the element of coercion this policy is only a mere satisfaction of the desire (statement of intent) (Ardial, 2010).

Political communication plays a very important role in the political system: political communication determines a dynamic element, and becomes a decisive part of political socialization, political participation, and political recruitment (Rush and Althoff, 2008). can also handle opinions or accusations of political opponents. Furthermore, political communication aims to attract sympathetic audiences in order to increase political participation in the lead up to the general election or regional head election (Ardial, 2010: 44).

\section{- Building a Political Image}

One of the goals of political communication is to build a good political image for the public. The political image is built or formed based on information that we receive, both directly and through political media, including mass media that work to convey general and actual political messages (Arifin, 2006).

\section{- Forming and Fostering Public Opinion}

The formation of public opinion in political communication, is largely determined by the role of political media, especially mass media. Indeed the press, radio, film and television, in addition to having the function of providing information, educating, connecting and entertaining, also mainly shape the political image and public opinion which are important dimensions in political life (Arifin, 2006). Each political system develops its own political communication network, and recognizes the importance of special sources; while the channels and listeners will differ according to the type of media used.

\section{- Encouraging Political Participation}

Political participation as a goal of political communication is intended so that individuals participate in political activities (political participation) (Arifin, 2006). So that one important form of political participation is when someone (the public) wants to vote for a politician or a particular political party in the general election.

\section{$>$ Political communication}

Political branding is used by political actors to gain popularity during the election campaign period (Downer, 2013). Shimp (2010) defines a brand as an identity that distinguishes a commodity in a marketing practice in the form of a product, service, individual, city or even country with its competitors and represents a set of symbolic and emotional values behind it. Schamell (2007) also explains that brand actually is a term that refers to a promise regarding self-privilege and the benefits offered to others. There is also what defines the brand as everything that arouses one's perception or thought when the name of the bran is mentioned (Chiaravalle and Schenck, 2007). Brand is not just an identification, but a symbolic representation of the identity of a marketing commodity or in this study it is assumed to be a political contest that has a specific purpose and represents the various values behind it.

There are three main reasons that branding becomes important in the practice of political campaigns (Scammell, 2015). First, branding provides symbolic value for the identification, meaning, value, benefits, promises, and differentiation of a political product. Second, branding is considered capable of influencing perceptions and giving confidence to constituents. Finally, branding is the result of interaction and emotional attachment that exists between political contestants and their constituents. So for this reason the true contestants need to consider branding as one of the weapons in their political campaigns.

Political branding does not necessarily guarantee victory in the hands of constituents. But political branding can be a powerful weapon for contestants in creating different and more efficient political campaigns (Cosgrove, 2012). Branding is a new form of political marketing. (Sonnies, 2011). Branding is defined as a psychological representation of a product / organization that is more directed to symbols rather than the use of tangible values. The idea of branding itself is more than a theory that can be applied to cities, countries and even politicians by giving them a public identity. 


\section{METHOD}

This research uses a qualitative approach. Bogdan and Taylor in Moelong (2006) define qualitative research as research that produces descriptive data in the form of written or oral words from people. The method to determine the informants in this study, the authors use purposive sampling that is choosing informants with certain criteria. In determining the informants of the researchers used informant entrepreneur Ryan Kono who is currently the deputy mayor of Gorontalo

Data collection methods in this study are the sources of literature and documentation, namely data collection techniques by viewing, recording, and analyzing secondary data that is done by taking data related to the issues discussed, as well as other sources of literature relevant to the problem be the object of research. The technique used in the validity of data is the triangulation of data validity checking techniques that utilize something other than the data for the purposes of checking or as a comparison of that data. In this study using triangulation with sources that is comparing and checking back the degree of trust in information obtained through time and different tools in qualitative methods

\section{RESULTS AND DISCUSSIONS}

\section{$>$ Political Process of businessmen be a succes politicians.}

Election of regional heads as a form of manifestation of democratic politics in practice shows two completely different faces, the first face shows the dark side of regional elections. Based on this side, the election of regional heads is only used as a venue for power struggles by a handful of elite political parties to gain power in regional executive institutions. Political parties that should be merely instruments for presenting the best candidates for the community tend to prioritize candidates who are loyal to superiors rather than candidates outside parties who might be considered to be more qualified and deserve to be regional leaders. It is not impossible that the control of parties over regional heads seems to be the target of political battles in national elections in both the legislative and presidential elections. This means that the election of regional heads is an instrument of the elite ambitions of the party to cultivate power to seize strategic positions.

Election of regional heads explained by each pair of candidates certainly competing with each other in attracting public interest to vote, as in the purpose of political communication, that political communication aims to attract sympathetic audiences in order to increase political participation before the general election or regional head election (Regional head election) (Ardial , 2010: 44). Not only political communication is carried out carefully in the face of competition in the election, but a strategy is also needed, in order to achieve the expected goals. Political communication strategies are needed to prepare in competing with opponents of other candidates, as well as forming an image positive in the eyes of the community. In dealing with elections like this, the candidate pairs, the campaign team and the supporting party must have prepared a well-planned plan, so that the strategy that it carries is right on target or successful. In the campaign period, the pairs of candidates compete to be elected, in which the community as the goal is to convey political communication related to the political goals of the candidates. Society is the biggest hope for the candidate pairs, a strategy that is carried out with a mature and organized course can attract audiences to vote.

One of the cases in the election of regional heads in Gorontalo City is an interesting phenomenon to be investigated related to political communication conducted by a businessman who is one of the candidates for deputy mayor. The entrepreneur who became a politician and is currently the mayor of Gorontalo is Ryan Kono. The first time, Ryan Kono's election as Gorontalo mayor's representative was started with Marten Taha's selection of representative figures, a number of figures who were close to him were the best figures. However, Marten Taha admitted that he did not want to be careless in choosing and determining the candidate for Deputy Mayor who will assist him in the upcoming 2018 Election of Mayor. Marten Taha even admitted that he did not want to determine the prospective companion as freely or according to his own taste. Because, Marten assesses, the determination and selection of regional head pairs is not an event that can be set according to their own desires. In the process, of course, it must be followed by rules and policies that meet all interests. Therefore, regarding someone who will accompany as a candidate for Deputy Mayor, Marten Taha submitted the decision entirely in accordance with the wishes of the people and also according to the policies of the political parties that will carry it. That is, in addition to having to dig out the sound from the lower layers,

Marten Taha also admitted that he must submit to the decisions and attitudes of the political parties that shelter him at the same time from the political parties that will carry and support him. And, only with such a process and mechanism, Marten Taha can automatically find the ideal Deputy Mayor candidate who will assist him in the 2018 Mayoralty Election. various parts of Gorontalo City also seem to be more inclined to speak out by saying one name, namely Ryan Kono. Marten finally confirmed the name as a figure who would accompany the Election of Gorontalo mayor in 2018. Marten Taha told reporters that he finally opened his mouth and admitted that he would pair up with Ryan Kono in the 2018 Gorontalo Mayor and Deputy Mayor election.

Young businessman Ryan Kono advanced in the mayoral election in 2018. Ryan Kono advanced to become the representative of Gorontalo City in partnership with Marten A Taha. Ryan Kono is a businessman who has political instincts, and is talented. Ryan Kono was already in politics at a very young age. Ryan Kono's political career could be supported by his experience as the chairman of Gorontalo HIPMI. It did not take long to learn, especially since his father was a reliable politician. Gorontalo Deputy 
Mayor Ryan Kono was elected for a term of 2019-2024 and was appointed by Gorontalo Governor Rusli Habibie at the Gorontalo Governor's official residence on June 2, 2019. Figure 1 shows the nomination of the 2018 Gorontalo regional head election.

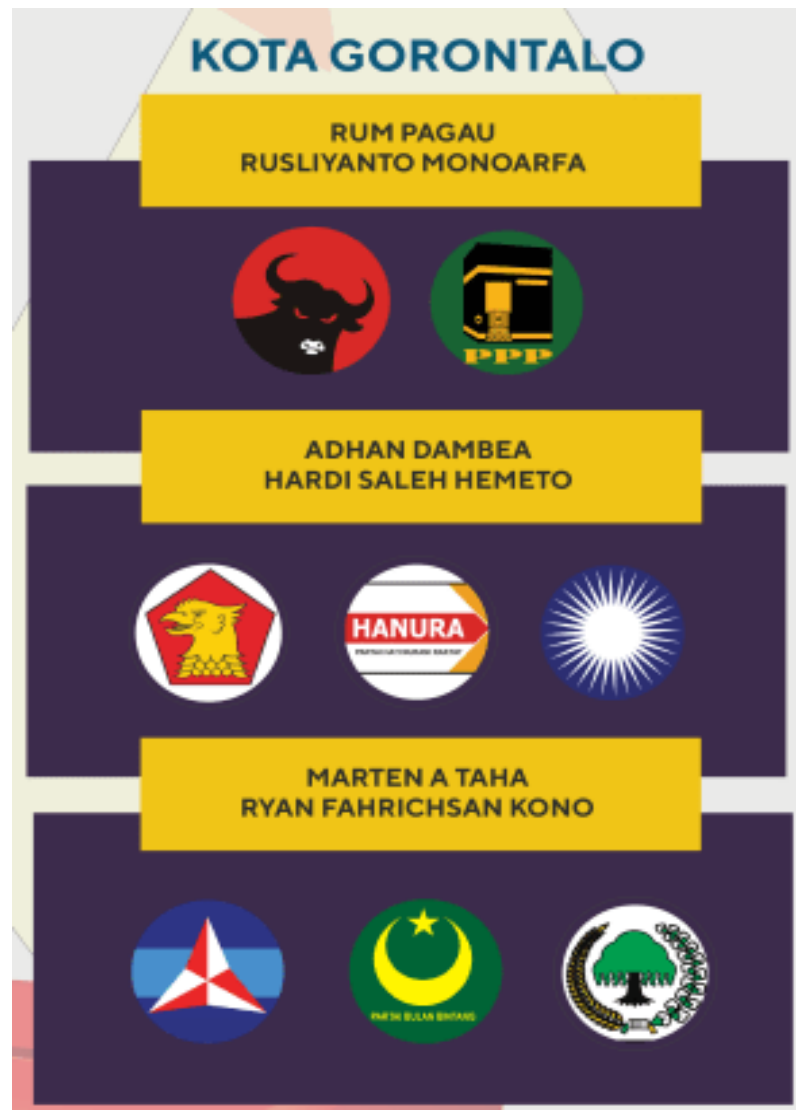

Fig 1:- Composition of Election of Gorontalo Regional Head in 2018

Figure 1 explains that there are three strong candidates for Gorontalo regional head election, including Rum Pagau-Rusliyanto supported by PDI and PPP, Adhan Damera and Hardi Saleh supported by Gerindra, Hanura and Pan while Marten A Taha and Ryan Kono are supported by the Bulan Bintang, Demorat and Golkar. Marten Taha-Ryan Kono was determined as a candidate for Mayor and Deputy Mayor of Gorontalo City or Paslon Matahari based on Decree of Gorontalo City KPU Number: 10 / HK.03.1.3-Kpt / 7571 / KPU-Kot / II / 2018 dated 12 February 2018.

Ryan Kono is a businessman chosen in one of the regions participating in the simultaneous regional head election is Gorontalo City. The dynamics of local politics ahead of the election of Gorontalo mayor increasingly lively ahead of the voting day. The enthusiasm of the regional head election is increasingly visible on the surface, with a variety of political maneuvers carried out by each pair of candidates for mayor. There are three candidate pairs (candidate pairs) who advanced in the Gorontalo mayor election, including Adhan Dambea-Hardi Hemeto, Marten Taha-Ryan Kono and Rum Pagau-Ruslianto Monoarfa. The details of the calculation of vote acquisition by each candidate pair (paslon), Sukrin explained, namely candidate pair number 1 (one) Adhan Dambea-Hardi Hemeto (ADHA CBD) 37,032 votes. Candidate pair number 2 (two), Marten Taha-Ryan Kono (MATAHARI) won 42,398 votes. While the candidate pair of serial number 3 (three), Rum Pagau-Ruslianto Monoarfa (RAMAH) won 23,281 votes.

The results of vote acquisition from the regional head election in Gorontalo City through quick counts through the KPU Vote Count Information System (Situng) Information System, for North Gorontalo District, the pair Indra YasinThariq Modanggu excelled by 31,466 or 43.74 percent on Wednesday. Gorontalo mayor candidate pair (Cawali) incumbent Marten Taha-Ryan F. Kono also won with 42.665 results or 41.20 percent. Based on the North Gorontalo KPU calculation, the second most votes was paired by candidate number 3 , Roni Imran-Ismail Patamani, with the result of 23,151 votes or 32.18 percent, and the third highest number of pairs of Idrus M.T Mopili-Suhela got 17,322 votes or 24.08 percent. The Roni-Ismail pair only excelled in the Four districts namely Tomolito District 3,193 votes, Ponelo Kepulauan District 6,399, and Anggrek District 3,629 votes, and Kwandang District 6,399 votes while Indra-Thariq paslon was superior in seven other districts. While for the Gorontalo Regional Election, candidate number 1 Adhan Dambea-Hardi S Hemeto received 37.386 votes or 36.09 percent, and candidate number 3 Rum Pagau-Rusliyanto Monoarfa received 23,524 votes or 22.72 percent. From the results of the data obtained, Marthen-Ryan excels in seven sub-districts while two other sub-districts namely Dungingi and Sipatana Districts are won by the Adhan-Hardi candidate pair. The final result of this calculation is the Gorontalo City regional election victory obtained by Marten Taha-Ryan F. Kono

\section{Strategic political communication be a succes politicians.}

In order to win a competition in general elections, of course it cannot be separated from the existence of several winning strategies, one of which is by developing a political communication strategy. Ryan Kono's strategic political communication in creating political branding includes:

\section{$>$ Internal Political Communication}

Ryan Kono's is supported by 5 parties in the Gorontalo City DPRD, namely the Golkar y, Democratic Party Bulan Bintang, Perindo and Hanura parties. In addition to that, the nomination of Ryan Kono was alo supported by the Former Governor, and the Former Deputy Governor of Gorontalo, the Governor and Deputy Governor of Gorontalo, members of the DPR-RI Dapil Gorontalo, and some political figures both in the city of Gorontalo and at the provincial level of Gorontalo.

Ryan Kono conducted political communication with the administrators of Democratic, Bulan Bintang, Perindo and Hanura parties from the regional level to the branches. Ryan Kono does not want a split in the internal party, which later could actually be a barrier in winning the 
regional head election. Ryan Kono by lobbying politics and imaging the internal party. Although Ryan Kono is a new politician who jumped into the Gorontalo political stage, but his track record can be relied upon by the public. Based on a qualitative assessment during the selection process, Ryan Kono has outperformed the other two candidates. Then Ryan Kono does have access to communication in the central government, so that it is expected that Golkar and the community can bring change to Gorontalo. Therefore, with these considerations, it was decided to carry Ryan Kono.

The activities carried out by Ryan Kono can be categorized as part of a dialogical political lobbying process. So that the expected outcome of the political lobbying is the existence of mutual understanding and agreement which will later be strengthened through formal talks in political meetings or hearings that will produce certain political decisions and attitudes. In this case, Ryan Kono was finally able to convince the cadres of Democratic Party and the Bulan Bintang Party and supported by the Perindo and Hanura Party in Gorontalo District to provide their voting support.

\section{Formation of a Success Team}

In addition to conducting political communication with internal parties, Ryan Kono also had to think about how to win the sympathy of Gorontalo people in the elections. In this case, of course, they were assisted by the success team to win the Gorontalo elections in 2010. Together with this success team, the political messages they brought were conveyed throughout Gorontalo District.

The formation of a successful team was carried out for socialization and consolidation at all levels of the movement. The formation of the team starts from the district, sub-district level, to the branch level. The composition of the campaign team and its winners consists of the person in charge, advisor, chairman and deputy chairman, secretary and deputy secretary, treasurer and deputy treasurer, several departments (public relations, issues and propaganda; logistics; socialization, mass campaign and mobilization; law and advocacy; witnesses and reporting, and campaigners), and coordinators in each district.

The success team that was deployed in the Gorontalo District Election was not only from structural members of Democratic, Bulan Bintang, Perindo and Hanura parties, but also from people outside the structural party. There are at least two successful teams that work in an organized and well-coordinated way, namely the official team and the volunteer teams. The formation of the Ryan Kono campaign team was basically a combination of a team of candidates for regional head and deputy regional head and party, which is under one coordinator.

\section{Coordination and Outreach}

After the successful team was formed, the next party's agenda was to declare Ryan Kono. Next, the campaign and winning team held a coordination meeting to determine strategic steps in winning the Ryan Kono. The results of the meeting mandated coordination and outreach to all levels of party elements both at the branch and branch level, coordination and outreach in all levels of the DPR board of Democratic, Bulan Bintang, Perindo and Hanura parties.

Road Show coordination and outreach to all levels of party elements. After the Road Show, the campaign team as well as the candidates for the regional head and deputy head of the region held an evaluation and coordination meeting to determine the next winning steps. In addition, the team and the candidates carried out socialization on an average of 5-10 days a day, and as part of an orderly management to synchronize the socialization it was decided that there was a "Ryan Kono supporter movement and set a scheduling gate at the Golkar Regional Secretariat in Gorontalo.

The implementation of the coordination and outreach activities has a political side, that is when a number of masses gather, then the impression of the community begins to build that the candidate is popular, the team is solid, and the support of the real mass. Because basically this coordination and outreach activity functions to consolidate the team to be able to burn their spirits, so that eventually they want to move to support Ryan Kono. It served as an introduction to Ryan Kono as a candidate for regional head and deputy regional head to the community.

\section{$>$ Political Campaign}

The campaign is one of the election agenda that must be passed and utilized as well as possible by all candidates for the election. The campaign was carried out in the context of socialization, raising mass supporters and to increase team solidity. Basically, the campaign is carried out by Ryan Kono candidates. This campaign team candidates by offering Ryan Kono's vision and mission or program orally or in writing to the public, to convince voters in order to get maximum support. Campaign planning that is not maximal will affect voters, the success team, and the image of the candidates themselves.

From a long time ago Democratic, Bulan Bintang, Perindo and Hanura parties had begun launching a campaign strategy aimed at socializing candidates and mobilizing as much support as possible. The concept of Democratic Party, Bulan Bulan, Perindo and Hanura campaigns is more dialogical, meaning that the campaign is face to face. The face-to-face campaign, which is the agenda going to the market and meeting citizens, is considered the best-selling and the best approach

By considering a number of things, such as the characteristics of the voters, the geographical location of the campaign location, and the cultural factors of the local community, campaign activities are carried out using certain methods that are considered the most able to influence the mass of voters. In addition, the methods chosen must be effective, efficient, and with minimal cost (saving). This is because given the limited source of campaign funding in the elections. Thus the campaign 
activities are carried out by means of a community gathering agenda, limited meetings between party internal officials, public meetings, down to market agendas, mounting pictures or other props and social actions, such as fogging (fogging).

The victory process obtained by one of the mayor's pairs, Ryan Kono, was inseparable from the political communication strategy carried out in the campaign process. Carrying "After the Sun Rises in the Sun" in each of its campaigns, Marten Taha-Ryan F. Kono promises to change and improve natural, economic, social welfare, health, policies. Marten Taha-Ryan F Kono. then use digital media as a means to market ideas, solicit support, and raise funds from its constituents. The speed and flexibility of digital media are used to reach out and interact directly with constituents. A series of activities carried out during the campaign period formed a political branding of him as a figure of a leader who represents the aspirations of young people and minorities and is ready to give a new color in the government system. The results in an instant Marten Taha-Ryan F. Kono was able to arouse people's participation, hopes and enthusiasm which later made Marten Taha-Ryan F. Kono become the mayor and vice mayor of Gorontalo in 2018. Ryan Kono's personal branding belongs to Ryan Kono's advantage as a businessman opening up the opportunity for him to win the election as deputy mayor of Gorontalo. Entrepreneur Ryan Kono has a strategy to successfully get votes and be elected as people's representatives. Therefore, the existence of political communication plays an important role in the political achievement of candidates for the people's representatives.

\section{RECOMENDATION}

Based on the description of the discussion the following conclusions are explained 1) Political process of businessmen be a succes politicians carried out with the initial process Ryan Kono advanced to represent Gorontalo City in partnership with Marten A Taha. Ryan Kono is a businessman who has political instincts, and is talented. Ryan Kono was already in politics at a very young age. Ryan Kono's political career can be supported by his experience as an entrepreneur. This supports the victory of Ryan Kono with the results of voting from the elections in Gorontalo City through quick counts through the superior Vote Counting Information System (Situng) with a result of 42.665 or 41.20 percent and 2) Political communication strategies promise change and improvement of natural policies in the fields of economy, social welfare, health, using digital media as a means to market ideas, solicit support, and raise funds from their constituents. Other strategic political communications include internal Political Communication, Formation of a Success Team, Coordination and Outreach and Political Campaign

\section{REFERENCES}

[1]. Ardial. (2010). Komunikasi Politik. Jakarta: PT Indeks.

[2]. Arifin, Anwar. (2006). Komunikasi Politik: Filsafat, Paradigma, Teori, Tujuan, Strategi, dan Komunikasi Politik Indonesia. Yogyakarta: Graha Ilmu.

[3]. Chiaravalle, Bill, dan Barbara Findlay Schenck.2007. Branding for Dummies. Hoboken,. NJ: For Dummies

[4]. Dan Nimmo. (2005). Komunikasi Politik. Bandung: PT Remaja Rosdakarya.

[5]. Downer, L. (2013). Political Branding in Australia: a Conceptual Model. 63rd Political StudiesAssociation Annual International Conference. Cardiff: Political Studies Association.

[6]. Gelder, S. V. (2003). Global Brand Strategy : Unlocking Brand Potential Across Countries.

[7]. London: Kogan PageHallahan, K., Holtzhausen, D., Van Ruler, B., Vercic, D., dan Sriramesh, K. 2007. Defining strategic communication. International journal of strategic communication, 1(1), 3-35.

[8]. Hasfi, Nurul, Hedi Pudjo Santosa dan Triyono Lukmantoro. 2014. The Role of Twitter in Political Communication in Indonesia Precidential Election 2014: The Face of New Democracy or Propaganda? Electronic copy available at: https://ssrn.com/abstract=3259342

[9]. Iazzolino, Gianluca and Stremlau, Nicole. 2017. Comparative Analysis Of Political Communication And Media Strategies In Conflict. All MeCoDEM Working Papers are available online and free of charge at www.mecodem.eu

[10]. Macnamara, J., and Zerfass, A. 2012. Social media communication in organizations: The challenges of balancing openness, strategy, and management. International Journal of Strategic Communication, 6(4), 287-308

[11]. McNair, B. (2003). An Introduction to Political Communication. New York London: Routledge Taylor and Francis Group.

[12]. McNair, Brian. (2003). An Introduction to Political Communication. New York-. London: Routledge

[13]. Milewicz, C. M., and Milewicz, M. C. (2014). The Branding of Candidates and Parties: The U.S. News Media and the Legitimization of a New Political Term,. Journal of Political Marketing, 13(4), 233263.

[14]. Moleong, j, Lexy. 2006. Metodologi Penelitian Kualitatif. Bandung: PT. Remaja. Rosdakarya

[15]. Neron, Pierre-Yves. 2010. Business and the Polis: What Does it Mean to See Corporations as Political Actors?. Journal of Business Ethics (2010) 94:333352 _ Springer 2009 DOI 10.1007/s10551-009-0266-y

[16]. Philbrick, J. L., and Cleveland, A. D. (2015). Personal Branding: Building Your Pathway to professional Success. Medical Reference Services Quarterly, 181189

[17]. Rush, Michael dan Althoff, Philip. (2008). Pengantar Sosiologi Politik. Jakarta : Rajawali Press 
[18]. Sampedroo, Victor. (2011). Introduction: New Trends and Challenges in Political Communication. The International Journal of Press/Politics. November Vol. 1No.1

[19]. Scammell, M. (2015). Politics and Image: The Conceptual Value of Branding. Taylor and FranciJournal of Political Marketing, 14(1-2), 7-18.

[20]. Scherer, Andreas Georg, Guido Palazzo dan Dirk Matten.(2009). The Business Firm as a Political Actor A New Theory of the Firm for a Globalized World. Call for Papers for a Special Issue of Business and Society. Volume XX No. X

[21]. Shimp, Terence A. (2010). Integrated Marketing Communication in Advertising and Promotion, $8 e$. South-Western: Cengage Learning

[22]. Sonies, S. (28 April 2011). Consumer Branding in Politics: A Comparison of Presidents Ronald Reagan and Barack Obama. Diakses pada 2 Juli 2020 dari https://american.edu/soc/communication/upload/Sarah -Sonies.pdf

[23]. Vreese, Claes H. de, Frank Esser, Toril Aalberg, Carsten Reinemann, James Stanyer. (2018). Populism as an Expression of Political Communication Content and Style: A New Perspective Show less. The International Journal of Press/Politics. Agustus Vol. 3 No. 1

[24]. Williams, C. B. 2016. Introduction: Social Media, Political Marketing and the 2016 U.S. 